\title{
Expression of Corynebacterium glutamicum glycolytic genes varies with carbon source and growth phase
}

Correspondence

Hideaki Yukawa

mmg-lab@rite.or.jp

Received 14 November 2006

Revised 4 February 2007

Accepted 28 March 2007

\author{
Sung Ok Han, ${ }^{1,2}$ Masayuki Inui ${ }^{1}$ and Hideaki Yukawa ${ }^{1}$ \\ ${ }^{1}$ Research Institute of Innovative Technology for the Earth, Kyoto 619-0292, Japan \\ ${ }^{2}$ School of Life Sciences and Biotechnology, Korea University, Anam-dong, Sungbuk-gu, \\ Seoul, Republic of Korea
}

\begin{abstract}
A basic pattern of gene expression and of relative expression levels during different growth phases was obtained for Corynebacterium glutamicum $\mathrm{R}$ grown on different carbon sources. The gapA-pgk-tpi-ppc gene cluster was transcribed as a mono- or polycistronic mRNA, depending on the growth phase. The $1.4 \mathrm{~kb}(g a p A)$ and $2.3 \mathrm{~kb}$ (pgk-tip) mRNAs were expressed in the early through late exponential phases, whereas the $3.7 \mathrm{~kb}$ (gapA-pgk-tpi) and $5.4 \mathrm{~kb}$ (pgk-tpi-ppc) mRNAs were only detected in the mid-exponential phase. All other glycolytic genes except $p p s$, $g l k$ and pgi were transcribed as monocistronic mRNAs under all tested conditions. Identification and alignment of the promoter regions of the transcriptional start sites of glycolytic genes revealed strong similarities to the $\sigma^{\mathrm{A}}$ consensus promoter sequences of Gram-positive bacteria. All genes involved in glycolysis were coordinately expressed in medium containing glucose. Growth in the presence of glucose gave rise to abundant expression of most glycolytic genes, with the level of gapA transcript being the highest. Glucose depletion led to a rapid repression of most glycolytic genes and a corresponding two- to fivefold increased expression of the gluconeogenic genes $p p s, p c k$ and $m a / E$, which are induced by pyruvate, lactate, acetate and/or other organic acids.
\end{abstract}

\section{INTRODUCTION}

Corynebacterium glutamicum, a nonpathogenic, Grampositive soil bacterium, is widely used for industrial production of numerous metabolites including amino acids and organic acids (Kinoshita et al., 1957; Liebl, 2005). In addition, it has gained increasing interest as a suitable model organism for the Corynebacterineae, a suborder of the Actinomycetes which also includes the medically important pathogenic genera Corynebacterium and Mycobacterium (Dover et al., 2004; Funke et al., 1997). C. glutamicum is able to grow on a variety of carbohydrates and organic acids as sole carbon and energy sources (Kinoshita \& Tanaka, 1972; Liebl, 1991). Due to the commercial importance of the amino acids produced by $C$.

Abbreviations: CCR, carbon catabolite repression; CRP, cAMP receptor protein; CBS, CRP-binding site; DO, dissolved oxygen; EMSA, electrophoretic mobility shift assay; GAPDH, glyceraldehyde-3-phosphate dehydrogenase; ORP, oxidation-reduction potential; qRT-PCR, quantitative real-time reverse transcription-PCR; RLM-RACE, RNA ligasemediated rapid amplification of cDNA ends.

The GenBank/EMBL/DDBJ accession numbers for the nucleotide sequences of C. glutamicum R glk, gpm, pfk, pgi, ptsG, fba, pps, eno, gapB, malE, pck, aceE and pgm are DQ248860-DQ248872; for tpi, gapA, pgk and ppc DQ248873; for pyk and Ipd AP009044; and for pyc AB115090. glutamicum, the catabolic and anabolic pathways leading to these amino acids have been studied in detail (Chassagnole et al., 2003; Dominguez et al., 1998; Eikmanns, 2005; Sahm et al., 1995; Wittmann \& De Graaf, 2005; Yokota \& Lindley, 2005). Among these pathways, glycolysis not only generates precursors for anabolism but also improves efficiency by substrate-level phosphorylation. The control of activity of glycolytic enzymes has been the subject of intensive studies, and phenotypes of mutants affecting glycolytic genes have been analysed (Eikmanns, 1992; Gourdon et al., 2000; Gubler et al., 1994; Inui et al., 2004; Netzer et al., 2004; Omumasaba et al., 2004; Park et al., 2000; Peters-Wendisch et al., 1998; Riedel et al., 2001; Schreiner et al., 2005). However, limited work has been devoted to the regulation of the C. glutamicum glycolytic pathway at the level of gene expression.

Although several studies of genome-wide expression analysis of C. glutamicum using DNA microarrays were recently reported (Barreiro et al., 2004; Huser et al., 2003, 2005; Muffler et al., 2002), the only individual glycolytic transcripts of $C$. glutamicum that have been characterized are the gapA cluster and $p y c$ gene (Peters-Wendisch et al., 1998; Schwinde et al., 1993). More than a decade ago, Schwinde et al. (1993) identified the genetic organization of the C. glutamicum gapA cluster corresponding to gapA, 
$g a p A-p g k-t p i, p g k-t p i$, and $p g k-t p i-p p c$. They also determined the transcriptional initiation sites, which were located in front of gap and $p g k$. Recently, analysis of biochemical properties and physiological roles of gapA and gapB of C. glutamicum encoding glyceraldehyde-3-phosphate dehydrogenases (GAPDHs) demonstrated that the enzyme encoded by gapA is active in glycolysis, whereas the gap $B$ product acts in gluconeogenesis (Omumasaba et al., 2004). Transcriptional analyses revealed that aceE (Schreiner et al., 2005), lpd (Schwinde et al., 2001) and pyc (Peters-Wendisch et al., 1998), encoding C. glutamicum pyruvate dehydrogenase, lipoamide dehydrogense and pyruvate carboxylase respectively, are monocistronic (2.9, 1.6 and $3.5 \mathrm{~kb}$ mRNAs respectively). Their respective transcripts are initiated at $\mathrm{A}, \mathrm{G}$ and $\mathrm{A}$ residues located 121,0 and $55 \mathrm{bp}$ upstream of the respective translational starts. Riedel et al. (2001) reported that the pck gene, encoding phosphoenolpyruvate carboxykinase, was monocistronic $(2.0 \mathrm{~kb})$ and that its transcription in lactategrown cells of C. glutamicum was higher than in glucosegrown cells.

Therefore, important fundamental questions still remain to be answered at the transcriptional level. For example, what is the transcriptional pattern, and how are the genes regulated? In particular, is the expression of the different glycolytic enzymes coordinately regulated by a shared mechanism? Transcriptional analysis of Bacillus subtilis revealed that glycolytic genes encoding enzymes that perform irreversible steps are induced by glucose and other sugars while those enzymes that are required for both glycolysis and gluconeogenesis are synthesized in both the presence and absence of sugars (Ludwig et al., 2001). Studies of genomic expression of seven glycolytic enzymes in Saccharomyces cerevisiae indicated that constitutive synthesis of glycolytic enzymes occurred when cells were grown in the presence of glucose (Hauf et al., 2000).

Glucose controls utilization of alternative carbon sources by regulating gene expression in response to glucose depletion (de Crombrugghe et al., 1984; Kolb et al., 1993). Carbon catabolite repression (CCR) is an environment-sensing mechanism used by bacteria for establishing priorities in carbon metabolism. The transcriptional regulator GlxR from C. glutamicum, which is involved in modulating expression of acetate regulation $(a c e B)$ and gluconate catabolism (gnt), shares $27 \%$ identity in amino acid sequence and the presence of cAMP-binding domain with cAMP receptor protein (CRP) from Escherichia coli (Kim et al., 2004; Letek et al., 2006). Kim et al. (2004) showed the heterologous complementation of E. coli CRP mutants by GlxR protein and suggested a possible interaction of GlxR with other promoters. However, the CCR mechanism in B. subtilis is different and is not based on the presence of a typical CRP able to bind or respond to cAMP (Lorca et al., 2005; Saier et al., 1995). In contrast to E. coli or B. subtilis, no direct evidence was found of a CCR system in C. glutamicum (Bruckner \& Titgemeyer, 2002; Gerstmeir et al., 2003; Stulke \& Hillen, 2000). The regulation of C. glutamicum metabolism in the presence of various carbon sources is clearly different from that of $E$. coli or B. subtilis (Gerstmeir et al., 2003; Hayashi et al., 2002; Muffler et al., 2002). However, the mechanisms of true induction/repression in the glycolysis pathway have not been studied in depth.

The objective of this study was to perform a detailed transcriptional analysis of genes encoding glycolytic enzymes by characterizing the lengths and start sites of the transcripts. The study also focused on the effects of culture conditions (carbon source and growth phase) on mRNA levels of different sets of genes. One such set includes genes encoding glycolytic enzymes.

\section{METHODS}

Growth conditions and analytical methods. C. glutamicum R (Kotrba et al., 2001) was used as the source of genomic DNA and total RNA. The bacteria were precultured at $33{ }^{\circ} \mathrm{C}$ for $8-12 \mathrm{~h}$ in a $500 \mathrm{ml}$ flask containing $100 \mathrm{ml}$ nutrient-rich medium composed of (per litre): $2 \mathrm{~g}$ yeast extract, $7 \mathrm{~g}$ Casamino acids, $2 \mathrm{~g}\left(\mathrm{NH}_{4}\right)_{2} \mathrm{CO}_{3}, 7 \mathrm{~g}$ $\left(\mathrm{NH}_{4}\right)_{2} \mathrm{SO}_{4}, 0.5 \mathrm{~g} \mathrm{KH}_{2} \mathrm{PO}_{4}, 0.5 \mathrm{~g} \mathrm{~K}_{2} \mathrm{HPO}_{4}, 0.5 \mathrm{~g} \mathrm{MgSO}_{4} \cdot 7 \mathrm{H}_{2} \mathrm{O}, 6 \mathrm{mg}$ $\mathrm{FeSO}_{4} \cdot 7 \mathrm{H}_{2} \mathrm{O}, 4.2 \mathrm{mg} \mathrm{MnSO}_{4} \cdot \mathrm{H}_{2} \mathrm{O}, 0.2 \mathrm{mg}$ biotin, and $0.2 \mathrm{mg}$ thiamine, with $4 \%(\mathrm{w} / \mathrm{v})$ glucose. Cell growth was monitored by measuring the $\mathrm{OD}_{610}$, using a spectrophotometer (DU640, Beckman Coulter). Samples of a mid-exponential-phase culture were harvested by centrifugation $\left(8000 \mathrm{~g}, 4{ }^{\circ} \mathrm{C}, 10 \mathrm{~min}\right)$. The cell pellet was subsequently washed twice with mineral salts medium, which had the same composition as the nutrient-rich medium except for the absence of yeast extract and Casamino acids. The washed cells were resuspended at a final cell concentration corresponding to an $\mathrm{OD}_{610}$ of 0.1 in $500 \mathrm{ml}$ mineral salts medium in a 11 jar fermenter (BMJ01PI, Biott). The sole carbon and energy source was provided by glucose, acetate, pyruvate, lactate, citrate, succinate or malate (200 mM each). The $\mathrm{pH}$ was monitored using a $\mathrm{pH}$ controller (DT-1023, Biott) and maintained at 7.6 by supplementing the medium with $5 \mathrm{M} \mathrm{NH}_{3}$ and $1 \mathrm{M} \mathrm{HCl}$. Cultivation was performed at $33{ }^{\circ} \mathrm{C}$ with constant agitation (1000 r.p.m.) and aeration ( $1 \mathrm{vol} \mathrm{vol}^{-1}$ $\left.\min ^{-1}\right)$. Cell growth was also continuously monitored by measuring the $\mathrm{OD}_{610}$. Cultured samples were centrifuged $\left(10000 \mathrm{~g}, 4{ }^{\circ} \mathrm{C}, 3 \mathrm{~min}\right)$, and the supernatants were analysed for sugars and organic acids. The concentrations of glucose were measured by an enzyme electrode glucose sensor (BF-4, Oji Scientific Instruments,). Organic acids were quantified by high-performance liquid chromatograph (8020, Tosoh) equipped with an electric conductivity detector.

Nucleic acid isolation. Chromosomal DNA was isolated using a genomic DNA purification kit (Promega) according to the manufacturer's instructions. Total RNA was extracted from broth cultures using a Qiagen RNeasy kit with the following additional steps. Cultures were added to 2 vols RNAlater solution (Ambion) and centrifuged at $15000 \mathrm{~g}$ for $10 \mathrm{~min}$ at $4{ }^{\circ} \mathrm{C}$. The aliquots of cell material were incubated with lysozyme buffer $\left(5 \mu \mathrm{g} \mathrm{ml}^{-1}\right)$ for $10 \mathrm{~min}$, and immediately resuspended in RLT buffer containing $\beta$-mercaptoethanol (Qiagen RNeasy kit). The suspensions were subsequently disrupted using $0.1 \mathrm{~mm}$ Zirconia/Silica beads (BioSpec Products) via three $45 \mathrm{~s}$ cycles at a speed of $6.5 \mathrm{~m} \mathrm{~s}^{-1}$ in a Q-BIOgene FastPrep FP120 Instrument (Q-BIOgene). After removal of the cell debris, RNA was isolated using the Qiagen RNeasy kit following the manufacturer's instructions. Where necessary, a second DNase digestion was performed with RNase-free DNase (Promega) to completely remove the chromosomal DNA. RNA samples were stored at $-80{ }^{\circ} \mathrm{C}$ until used. 
Northern hybridization. RNA samples $(5 \mu \mathrm{g})$ were denatured in Glyoxal Load Dye (Ambion) at $50{ }^{\circ} \mathrm{C}$ for $30 \mathrm{~min}$ and separated through $1 \%(\mathrm{w} / \mathrm{v})$ agarose gels in Gel Prep/running buffer (Ambion). DNA probes were synthesized by PCR using specific oligonucleotides derived from the C. glutamicum sequence as templates (Table 1). The probes were non-radioactively labelled by random priming using DIG-High Prime (Roche). RNA was transferred overnight to a positively charged nylon membrane (Roche) by vacuum transfer (Bio-Rad) using $10 \times \mathrm{SSC}(1.5 \mathrm{M} \mathrm{NaCl}, 150 \mathrm{mM}$ trisodium citrate, $\mathrm{pH}$ 7.0). Hybridization was carried out for $2 \mathrm{~h}$ at $42{ }^{\circ} \mathrm{C}$ in ULTRAhyb buffer (Ambion). Washing of the membranes and detection of specific transcripts on the blots were performed by using a DIG luminescence detection kit (Roche) and a Luminescent Image Analyser LAS-1000 system (Fujifilm).

RT-PCR analysis. RT reactions were performed on total RNA using a commercially available reverse transcription system (Promega) with slight modifications to the manufacturer's recommended protocol. A final volume of $20 \mu \mathrm{l}$ containing $5 \mathrm{mM} \mathrm{MgCl}_{2}, 1 \times \mathrm{RT}$ buffer $[10 \mathrm{mM}$ Tris/HCl (pH 9. 0), $50 \mathrm{mM} \mathrm{KCl,} 0.1 \%$ (v/v) Triton X-100], $1 \mathrm{mM}$ (each) deoxynucleoside triphosphates, $1 \mathrm{U}$ recombinant RNasin RNase inhibitor, $15 \mathrm{U}$ avian myeloblastosis virus (AMV) reverse transcriptase, $0.25 \mu \mathrm{M}$ oligonucleotide primer and $10 \mu \mathrm{g}$ substrate RNA was incubated at $48{ }^{\circ} \mathrm{C}$ for $45 \mathrm{~min}$, and the reaction was terminated by heating the mixture to $95{ }^{\circ} \mathrm{C}$ for $5 \mathrm{~min}$, followed by incubation on ice for $5 \mathrm{~min}$. The resultant cDNA products were then amplified in $25 \mu \mathrm{l}$ PCR mixtures using $2.5 \mu \mathrm{l}$ RT reaction mixture as the template.

Quantitative real-time reverse transcription-PCR (qRT-PCR). The mRNA was quantified with an ABI Prism 7000 RT-PCR system (Applied Biosystems). For each RT-PCR reaction with each primer pair, using a QuantiTect SYBR Green RT-PCR kit (Qiagen) according to the manufacturer's instructions, $50 \mathrm{ng}$ total RNA was used. Negative controls with no reverse transcriptase were included with each RNA sample to rule out DNA contamination. DNA templates without reverse transcriptase were included as positive controls. Amplicons were run on a $2 \%(\mathrm{w} / \mathrm{v})$ agarose gel to verify that only a single band was produced. The target gene transcripts were normalized to the reference gene transcripts (16S rRNA) from the same RNA samples. Each gene was analysed using RNA isolated from three independent samples.

RNA ligase-mediated rapid amplification of CDNA ends (RLMRACE) PCR. The RLM-RACE technique was applied to total RNA extracted from a culture grown on glucose, and was used to determine transcription start points and transcriptional terminators. Rapid amplification of $5^{\prime}-$ or $3^{\prime}$ - cDNA ends was performed using the FirstChoice RLM-RACE kit (Ambion) according to the manufacturer's instructions. The PCR amplification products were observed on $2 \%(\mathrm{w} / \mathrm{v})$ agarose gels, and sequenced using an ABI PRISM 3100 genetic analyser (Applied Biosystems).

Purification of GIxR. Primers glxR-TF (5'-CACCGTGGAAGGTGTACAGGAGAT-3') and glxR-TR (5'-TCGAGCGCGACGTGCCAAAT- $\left.3^{\prime}\right)$ were used to amplify the glxR gene from C. glutamicum. The amplified $g l x R$ gene was cloned into pET100/D-TOPO, which allowed translational fusion between a C-terminal 6-His tag and a target gene, and was transformed into E. coli BL21 Star (Invitrogen) for overexpression. The enzyme was purified using a nickelnitrilotriacetic acid column (Invitrogen) and was dialysed against $20 \mathrm{mM}$ Tris ( $\mathrm{pH} 7.0$ ) and $1 \mathrm{mM}$ dithiothreitol. Where indicated, the 6-His-tag was removed by treatment with EnterokinaseMax (Invitrogen) after purification. Samples taken at different stages of the purification process and the purified protein were analysed by SDS-10\% PAGE as described by Laemmli (1970). Samples mixed with a Tris/glycine SDS sample buffer (Invitrogen) $(1: 1, \mathrm{v} / \mathrm{v})$ were denatured at $100{ }^{\circ} \mathrm{C}$ for 5 min and applied to a $10 \%$ polyacrylamide gel using a mini-Protean II system (Bio-Rad). Gels were stained with Colloidal Coomassie blue Stain (Genomic Solutions) to visualize proteins.

Electrophoretic mobility shift assay (EMSA). For testing the binding of GlxR to putative target promoters, purified GlxR protein (50-500 ng) was mixed with DNA fragments (mostly $200 \mathrm{bp}$; final concentration, $10-100 \mathrm{ng}$ ) in a total volume of $10 \mu \mathrm{l}$. The binding buffer ( $\mathrm{pH}$ 7.4) contained $150 \mathrm{mM} \mathrm{KCl}, 0.1 \mathrm{mM}$ dithiothreitol, $0.1 \mathrm{mM}$ EDTA, $10 \mathrm{mM}$ Tris and $0.2 \mathrm{mM}$ cAMP. The reaction mixture was incubated at room temperature for $30 \mathrm{~min}$ and then loaded onto a $5 \%$ native polyacrylamide gel. Electrophoresis was performed at room temperature and $200 \mathrm{~V}$ using $0.5 \times \mathrm{TBE}$ buffer ( $44.5 \mathrm{mM}$ Tris base, $44.5 \mathrm{mM}$ boric acid, $1 \mathrm{mM}$ EDTA) supplemented with $0.2 \mathrm{mM}$ cAMP. The gels were subsequently stained using the EMSA kit (Invitrogen) as described by the manufacturer and photographed. All PCR products used in EMSA were purified with the PCR purification kit (Qiagen) and eluted in distilled water.

Sequence analysis. DNA sequences were determined using BigDyeTM Terminator v3.0 Cycle Sequencing Ready Reaction kit (Applied BioSystems) on an ABI PRISM 3100 DNA sequencer (Applied Biosystems). The sequence analyses including mapping, alignment, promoter searches, annotation and illustration, and all database searches were performed using the Vector NTI software, version 9.1 (Invitrogen) and GENETYX-PC version 7.0 (GENETYX).

\section{RESULTS}

\section{Transcription of glycolytic genes}

In Northern blot analyses, membranes containing RNA were hybridized with intragenic probes derived from the glycolytic genes of C. glutamicum (Table 1). RLM-RACE analysis was designed to amplify cDNA only from fulllength mRNA, to enable the recovery of the $5^{\prime}$ and $3^{\prime}$ end of the mRNA transcripts. These experiments demonstrated the size of the transcripts and the relative location of the genes. The $p t s G, g p m, p f k$, fba, gapB, pgm, eno, aceE, lpd, $p y c, p c k$ and malE genes were transcribed as monocistronic transcriptional units with transcripts (protein-coding sequences) of 2.4 (2043), 1.7 (1665), 1.3 (1032), 1.2 (1035), 1.7 (1392), 0.8 (747), 1.4 (1278), 2.9 (2766), 1.5 (1410), 3.6 (3420), 2.0 (1830) and $1.3 \mathrm{~kb}$ (1176 bp) respectively (data not shown). The promoters of $p t s G$, $g p m, p f k, f b a, g a p B, p g m$, eno, aceE, lpd, pyc, pck and malE were located $255,26,0,148,132,45,70,118,0,56,37$ and $70 \mathrm{bp}$ directly upstream of the respective start codon (Fig. 1). RLM-RACE mapping analysis of $g l k$, $p g i, p y k$ and $p p s$ revealed that putative promoter and independent terminator structures were not found upstream and downstream of the respective genes (data not shown). A BLAST search of genomic databases of C. glutamicum (Ikeda \& Nakagawa, 2003; Kalinowski et al., 2003) indicated that $g l k$, pgi, $p y k$ and $p p s$ were not clustered with genes encoding other enzymes of the glycolytic pathway in their respective adjacent regions. All glycolytic genes, except $g l k, p g i, p y k$ and $p p s$ along with the gapA-pgk-tpi-ppc cluster, were transcribed as monocistronic mRNAs. 
Table 1. Oligonucleotide primers used in this study

\begin{tabular}{|c|c|}
\hline Primer name ${ }^{\star}$ & Sequence $\left(5^{\prime}-3^{\prime}\right)$ \\
\hline$p t s G-\mathrm{F}$ & GTCCAAACTGACGACGACAT \\
\hline$p t s G-5^{\prime}-$ In & ATCCTTCACTTGGAAGCGAA \\
\hline ptsG-5'-Out & CCATCAAGTTTGAGGATTTC \\
\hline ptsG-UF & CCGTTTTCGTTTTCAAAAAA \\
\hline$p t s G-\mathrm{UR}$ & ACAATTTGGCAAAAATTTTT \\
\hline$g l k-\mathrm{F}$ & CCACAAAAACCGGCCAGTTT \\
\hline$g l k-5^{\prime}-$ In & GTTCCATTGCCTGCGTCGTG \\
\hline$g p m-\mathrm{F}$ & GGCAACTCGCCCAACCAGAAGA \\
\hline$g p m-5^{\prime}-$ In & TCCGGAGGTACCGAAAGCGA \\
\hline$g p m-5^{\prime}-$ Out & TGGCTGCTGGTTGCGGTAAT \\
\hline$g p m-3^{\prime}-$ Out & AAGACCCCATCCCAGCGTTA \\
\hline$g p m-3^{\prime}-\mathrm{In}$ & GCGCAGCCATCGGAGGACTAAA \\
\hline$g p m-\mathrm{UF}$ & GATGGCCAGGATCGGCCAGG \\
\hline$g p m-\mathrm{UR}$ & ААСАССААТАСТТСТССТСС \\
\hline$p g i-\mathrm{F}$ & ATGGCGGACATTTCGACCAC \\
\hline$p g i-5^{\prime}-$ In & ACTTCTCGGCGCGGTTTTCT \\
\hline$p f k-\mathrm{F}$ & ATGGAAGACATGCGAATTGC \\
\hline$p f k-5^{\prime}-$ In & ACGACGGTGGAGCCAAATTC \\
\hline$p f k-5^{\prime}-\mathrm{Out}$ & AAACTTGTCCGGATGGAGGC \\
\hline$p f k-\mathrm{UF}$ & ACCACATGCCCGCTCGGACA \\
\hline$p f k-\mathrm{UR}$ & GCAGTCGCCGCCTGACGTGA \\
\hline$f b a-F$ & ATCGCAACTCCCGAGGTCTATAAC \\
\hline$f b a-5^{\prime}-$ In & GAGCTGCGTTGATGGTTTCC \\
\hline$f b a-5^{\prime}$-Out & CGAAGGCTGCAAGCGCAACT \\
\hline$f b a-\mathrm{UF}$ & TAGCCCCGATAGTGTATGTG \\
\hline$f b a-\mathrm{UR}$ & ATCATGCAGAAACATGGTGA \\
\hline$t p i-\mathrm{F}$ & GGCACGTAAGCCACTTATCGCT \\
\hline tpi-5'-In & GGTGACTGCAACGTCAACCT \\
\hline tpi-5'-Out & GGAGACGTCCTGAGCACCGAAA \\
\hline gapA-F & ACCATTCGTGTTGGTATTAACGGAT \\
\hline gapA-5'-In & TTGAGAAGGGTGGAAAGGGT \\
\hline gapA-5'-Out & GTGTGCAGCCCAGTCCAGGTTCTT \\
\hline gapA-UFS1 & TCGCTCGTCTCATAAAAACG \\
\hline gapA-URS1 & GCGCTAAATAGTTTTTGCAG \\
\hline gapA-UFS2 & TCATAATTAGCCCCATTCGG \\
\hline gapA-URS2 & AACTCCGTGTCAACCTGTCC \\
\hline$g a p B-\mathrm{F}$ & CGCCTGCACCGCAACAATAA \\
\hline$g a p B-5^{\prime}-$ In & CGGGCGTAGCGATGAGACTT \\
\hline$g a p B-5^{\prime}-$ Out & CCAGGTCGATCGATGCGGTA \\
\hline gapB-3' -Out & ATCCGTTCCCCAGAGGTTGT \\
\hline gapB-3'-In & GACAACGAGTTCGGCTACTC \\
\hline gapB-UF & GGGAACTGGGATTACGCCTA \\
\hline gapB-UR & TAAAAAGTCCTTCACTGACT \\
\hline$p g k-\mathrm{F}$ & ATGGCTGTTAAGACCCTCAAG \\
\hline$p g k-5^{\prime}-$ In & GTGATCTCGCGGTCATCGTT \\
\hline$p g k-5^{\prime}-$ Out & CTCAGCGACAGGTGCGAGGG \\
\hline$p g k-\mathrm{UF}$ & TTAGTTCACATCGCTAACGT \\
\hline$p g k-\mathrm{UR}$ & ATTTGATTGTTTAAAAAATT \\
\hline$p g m-\mathrm{F}$ & ATGCTGCATGTCATGAAGCC \\
\hline$p g m-5^{\prime}-$ In & CGCCTGACCAGGAAGAACCT \\
\hline$p g m-5^{\prime}-$ Out & TTTCCTGTGCACGCTCCATC \\
\hline pgm-3'-Out & TTTAGTCATGCCGACACGAT \\
\hline$p g m-3^{\prime}-$ In & AGGCGTCTCCTCCCATATGC \\
\hline$p g m-\mathrm{UF}$ & GCTGCGAAGTTTGGCTAGGAGG \\
\hline$p g m$-UR & GCTGCGTGTGAACCCGGCTT \\
\hline eno-F & CATGCACGTATTCGCTCGCG \\
\hline
\end{tabular}

\begin{tabular}{|c|c|}
\hline Primer name* & Sequence $\left(5^{\prime}-3^{\prime}\right)$ \\
\hline eno- $5^{\prime}$-In & CCTCGTGGACGCCGGTGGAT \\
\hline eno-5'-Out & GCGCTGATCGTCAGCCTCTA \\
\hline eno-3'-Out & GGCTACACCTCCATGATGTCTCA \\
\hline eno-3'-In & CGTTCCGACCGTGTCGCAAA \\
\hline eno-UF & AACTAAACAAGCGCAACCCC \\
\hline eno-UR & CTCCTATGCCAACTTGGGAG \\
\hline$p y k-\mathrm{F}$ & GGAGAAGTTGAGGCGAGCAA \\
\hline$p y k-5^{\prime}-$ In & ATGGGCGTGGATAGACGAAC \\
\hline$p p s-\mathrm{F}$ & ATGACCAACAGTTTGAACAT \\
\hline$p p s-5^{\prime}-$ In & TAGTGACCACAAATCCAGGT \\
\hline aceE-F & GTGGAAATGGCCGATCAAGC \\
\hline aceE-5'-In & GGTCTCCTCCGGATCTGAGT \\
\hline aceE-5'-Out & GAAGAGATACGCGCTTTGCA \\
\hline aceE-3'-Out & TGTCTGACTTCTCCACTGAT \\
\hline aceE-3'-In & TTGTTGTTGCCGTGCTGAAC \\
\hline aceE-UF & GAAATGTTCTTTGAAAAATCCAC \\
\hline aceE-UR & CCATTTTTGGTCGTACCTAA \\
\hline$l p d-\mathrm{F}$ & GTGACTGAACATTATGATGTAG \\
\hline$l p d-5^{\prime}-$ In & AACGTTAAGGCAGATACCAC \\
\hline$l p d-5^{\prime}-$ Out & TCGTAGTTGAAGGTGACTTC \\
\hline$l p d$-UF & TTAGATTTCGACTATCAACTGG \\
\hline lpd-UR & CATAATGTTCAGTCACGCAT \\
\hline$p y c-\mathrm{F}$ & GTGTCGACTCACACATCTTC \\
\hline$p y c-5^{\prime}-\mathrm{In}$ & TCACGGGGGTAAATAGCTAC \\
\hline pyc-5'-Out & CCCGGGTAAATAGCATCTGC \\
\hline$p y c-\mathrm{UF}$ & TTAAATGCGTTAAACTTGGC \\
\hline$p y c$-UR & ACTTCGTCCTAGTATCGTAA \\
\hline$p p c-\mathrm{F}$ & AGTAGTTATGACTGATTTTCTACGC \\
\hline$p p c-5^{\prime}-\mathrm{In}$ & TATCAAAAGAAGTCAGGCGC \\
\hline$p p c-5^{\prime}-\mathrm{Out}$ & GCCTGCATCGAGAGCCTGTT \\
\hline$p c k-\mathrm{F}$ & ATGACTACTGCTGCAATCAGG \\
\hline$p c k-5^{\prime}-$ In & CCTGGGATCCATCAACGAAC \\
\hline pck-5'-Out & GTTGGGCCAGCATCTTCTTC \\
\hline$p c k-\mathrm{UF}$ & GGGGACGGTTGAGGTTAATT \\
\hline pck-UR & TTCGACAGAGTTCTCGCCCC \\
\hline malE-F & ATGACCATCGACCTGCAGCG \\
\hline malE-5'-In & CAGGGGTGTAACCAAGGGAA \\
\hline malE-5'-Out & ATATCGCCAAGACCCAGAAC \\
\hline malE-UF & CAGCCCAAATTCAGCCCACT \\
\hline malE-UR & GGGTTCTGGAACAAAAACAC \\
\hline$a c e B$-UF & TTGGTGCGTCAATCGGTTTG \\
\hline aceB-UR & ATCTAGGTGCCGCTCTTCTT \\
\hline
\end{tabular}

* $-\mathrm{F}$ and $-5^{\prime}$-In, used for qRT-PCR; -F and $-5^{\prime}$-Out, used for Northern blot analysis; $-5^{\prime}$-In and $-5^{\prime}$-Out, used for 5'-RLM-RACE; - $3^{\prime}$-In and - $3^{\prime}$-Out, used for $3^{\prime}$-RLM-RACE; -UF \& -UR (including -UFS and -URS), used for EMSA.

Results of promoter analyses of all genes involved in glycolysis are summarized in Fig. 1. When the DNA sequences in the promoter regions were scanned for promoter-like -10 and -35 elements by Vector NTI and GENETYX software, candidate sequences were easily identified. A -10 sequence identical to the consensus -10 (TATaaT) for the primary $\sigma^{70}$-type promoters in B. subtilis $\left(\sigma^{\mathrm{A}}\right)$ and E. coli $\left(\sigma^{70}\right)$ (Chang et al., 1992; Harley \& Reynolds, 1987) is shown. In looking for a pattern, the 


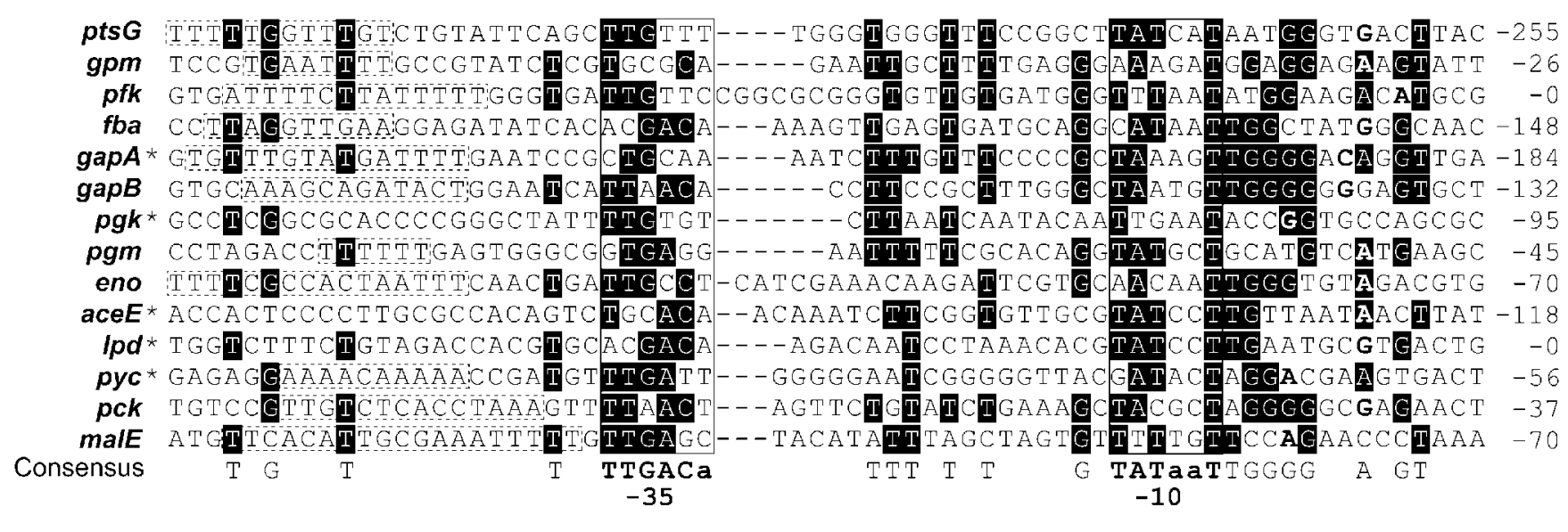

\begin{abstract}
Fig. 1. Determination and alignment of putative C. glutamicum promoters located 10 and 35 bases upstream of the transcription start point (TSP). TSPs were determined by sequencing of 5'-RLM-RACE PCR products, and are indicated by bold letters. The nucleotide numbering begins from the first codon shown on the right. The consensus sequence for the -10 and -35 promoter sequences derived from this alignment is given at the bottom. It consists of nucleotides that are present in any given position in more than $50 \%$ of the sequences. Promoter sequence nucleotides that match those of the consensus sequence are shown in black boxes. Asterisks $\left(^{*}\right)$ indicate previously mapped promoters: gapA and pgk (Schwinde et al., 1993), aceE (Schreiner et al., 2005), Ipd (Schwinde et al., 2001), and pyc (Peters-Wendisch et al., 1998). Their TSPs (except for pgk) are in agreement with the findings of this study.
\end{abstract}

strongest signal was clearly recognized in the -10 region, providing the consensus sequence TATAAT. Some bases upstream and downstream of the -10 hexamer (underlined) are conserved to GnTATaaTTGGGG. Obvious similarity was observed in regions between -10 and -35 with the consensus sequence TTTnTnT. This consensus sequence was not found in promoters of non-glycolytic genes described previously (Patek et al., 2003). The promoter regions of gapA and gapB genes, encoding GAPDH, were very similar in the -10 hexamer region and in the region between the -10 and transcriptional initiation site. According to the base distribution in the -35 region, the hexamer TTGACa was evaluated as the -35 consensus sequence. In addition, a number of promoters were found to contain AT-rich tracts within the region upstream of the -35 sequence (Fig. 1). These tracts may activate the promoters by DNA bending or forming an UP element (Perez-Martin et al., 1994). The UP element stimulates transcription through a direct interaction with the C-terminal domain of the RNA polymerase $\alpha$ subunit (Meng et al., 2001; Ross et al., 1998).

\section{Transcription of the gapA cluster at different growth phases}

The gapA, $p g k$, tpi and $p p c$ genes form a gene cluster (Fig. 2A). In order to determine gapA cluster transcriptional organization at different growth phases, RNA was isolated from glucose cultures at different growth phases (Fig. 2D). Transcription of operons such as gapA-pgk-tpi and $p g k-t p i-$ $p P c$ was the subject of a previous study (Schwinde et al., 1993). As observed previously, Northern analysis using the
gapA probe revealed two mRNAs, of $1.4 \mathrm{~kb}$ and $3.7 \mathrm{~kb}$ (Fig. 2B-1). Based on transcript sizes and Northern analyses using other probes such as pgk or tpi, the $2.3 \mathrm{~kb}$ and $3.7 \mathrm{~kb}$ mRNAs were demonstrated to correspond to bicistronic $p g k-t p i$ and tricistronic gapA-pgk-tpi transcripts, respectively, that are terminated at the terminator between $t p i$ and $p p c$ (Fig. 2B-2). However, the larger transcript (3.7 kb) was detectable only as a very faint band in all growth phases except the mid-exponential phase (Fig. 2B). In addition, the $5.4 \mathrm{~kb}$ mRNA represents a $p g k-t p i-p p c$ transcript (Fig. 2B-2) of the operon terminating at the terminator structure downstream of $p p c$. The levels of $16 \mathrm{~S}$ and $23 \mathrm{~S}$ rRNA (1.5 and $2.9 \mathrm{~kb}$ respectively, Fig. 2B-3) were constant throughout different growth phases, indicating that equal amounts of total RNA were loaded into each well of the gel.

Quantitative RT-PCR analysis showed that the level of expression of the intergenic region between the gapA and $p g k$ genes (Fig. 2C-ii) was significantly decreased compared to gapA or $p g k$ (Fig. 2C-i, C-iii). Transcripts of the intergenic region between the tpi and $p p c$ genes (Fig. $2 \mathrm{C}$-vi) were also at least 10 -fold lower than those of the intragenic regions on either tpi or $p p c$ (Fig. 2C-v, C-vii). However, expression levels of an intergenic region between the $p g k$ and tpi genes (Fig. 2C-iv), in which neither a promoter nor a terminator was found, were higher than those of $p g k$ (Fig. 2C-iii) and not significantly different from those of tpi (Fig. 2C-v).

The presence of the mono-, bi- and tri-cistronic transcripts suggested the existence of a promoter upstream of gapA and $p g k$. In agreement with the previous report (Schwinde et al., 1993), the gapA transcriptional start point was 
A
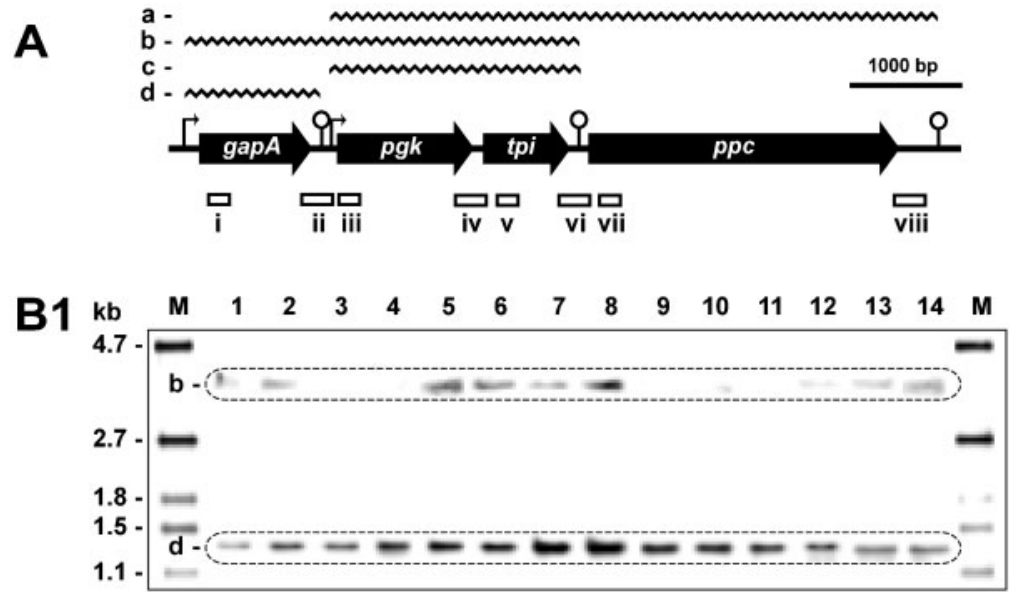

B2

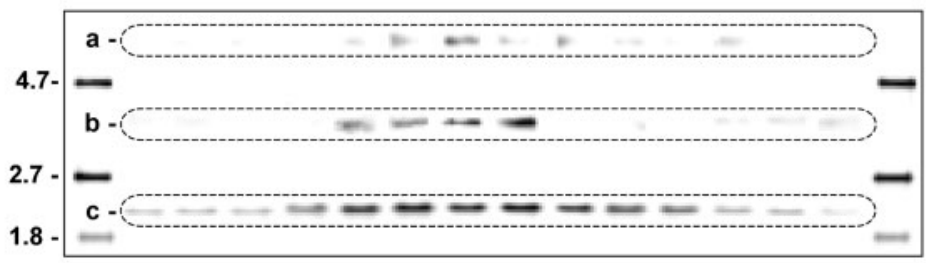

B3

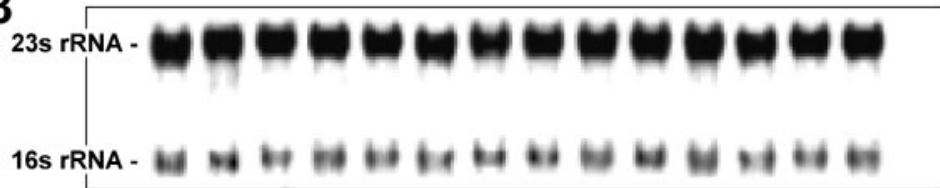

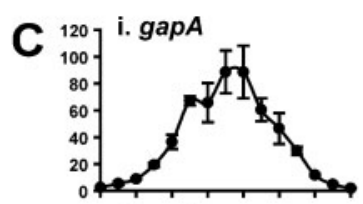

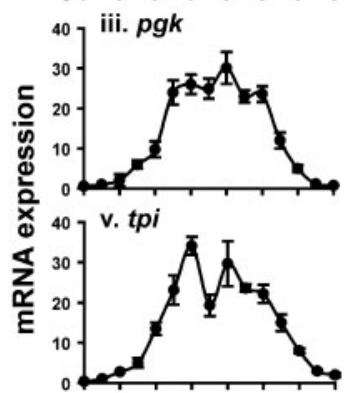

${ }^{20}$ vii. ppc

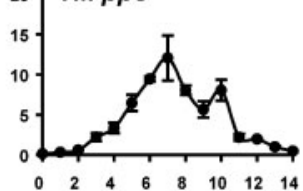

D

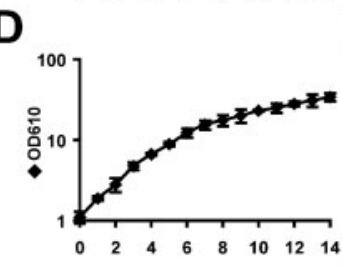

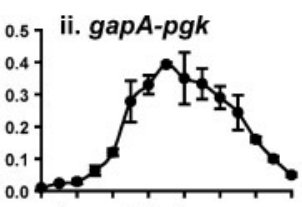

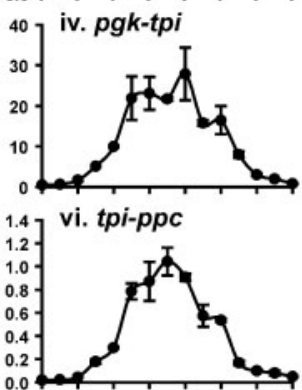

14 viii. ppc 3'-end

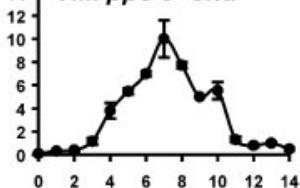

$E$

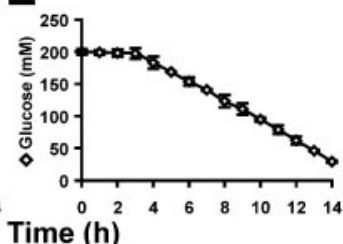

Fig. 2. Levels and sizes of transcripts of gapA cluster at different growth phases on glucose culture. (A) Scheme of genetic organization including genes (black arrows), transcripts (wavy lines), transcription start points (bent arrows), transcription termination points (stem-loops) and location of probes (open rectangles). (B) Northern blot analyses conducted with the same concentrations of RNA (5 $\mu \mathrm{g}$ ) with probes specific to gapA (B1-d), pgi-tpi (B2-c), gapA-pgi-tpi (B1-b or B2-b) and pgi-tpi-ppc (B2-a) genes. Ethidium bromide-staining of rRNA is shown as a loading control (B3). The numbers of the lanes in $B$ and the times on the graphs in $C$ represent the times on the growth curve in D. The sizes (kb) of DIG-labelled RNA molecular mass markers (lanes M, Roche) are indicated on the left. (C) Transcriptional expression was determined by quantitative RT-PCR with the same concentration of RNA ( $25 \mathrm{ng}$ ) isolated from C. glutamicum cultivated on mineral salts medium containing $200 \mathrm{mM}$ glucose as the sole carbon and energy source. Primers specific for the gapA-pgk-tpi-ppc genes and intergenic regions were used to amplify fragments by PCR (see Table 1). The locations of specific primer pairs (C, i-viii) are shown in A. For negative controls, the reactions were performed in the absence of RT or RNA templates (data not shown). (D) C. glutamicum growth curve $\left(\log _{10} \mathrm{OD}_{610}\right)$. (E) Time course of glucose concentration. The $\mathrm{pH}$ was maintained at 7.6.

identified at a single cytosine located 184 bases upstream of the ATG start codon (Fig. 1). On the other hand, the transcriptional start of $p g k$ was detected at a guanine residue 95 bp upstream of the ATG start site (Fig. 1), indicating that $p g k$ could be transcribed independently of gapA. However, this promoter region was different from that identified in previous experiments (Schwinde et al., 1993), in which the main signal indicated that it was 58 bp upstream of the ATG start codon. In the $p g k$ primer extension analysis by Schwinde et al. (1993), a main signal (-58) and several week signals were detected. The position at $95 \mathrm{bp}$ identified in this study, however, corresponded to neither a main signal nor a weak one. No promoter was observed upstream of tpi or $p p c$ (Figs 1 and 2). Comparison of the DNA sequences of all glycolytic genes between C. glutamicum R and those of C. glutamicum
ATCC 13032 (Ikeda \& Nakagawa, 2003) registered in the National Center for Biotechnology Information (NCBI) nucleotide databases revealed $97 \%$ identity both within the coding region and upstream of the coding region (data not shown). Complete (100\%) sequence identity of the promoter region between strain R and ATCC 13032 was observed upstream of $p g k$, but the location of the promoter was different between strains R and ATCC 13032.

\section{Relative expression levels of all genes involved in glycolysis at different growth phases}

To determine whether the glycolytic genes are coordinately regulated, changes in the expression levels of several glycolytic genes were monitored during the cultivation of 
C. glutamicum on glucose as the sole carbon source. RNA was prepared from the culture at different stages of growth (Figs 2D and 3S) and was subjected to qRT-PCR analyses using specific primer sets for the glycolytic genes (Figs 2 and 3; Table 1). To ensure that the resulting PCR products were amplified from cDNA and not contaminating chromosomal DNA, control experiments were performed in which reverse transcriptase or total RNA was omitted. In these controls, no signal was detected (data not shown).

As shown in Figs 2 and 3, the pattern of induction by glucose at different growth phases was very similar among all glycolytic gene transcripts. In the presence of glucose at the early stages of growth $(4 \mathrm{~h})$, all glycolytic gene transcripts were induced, with the level of gapA mRNA being the highest. As the culture entered the exponential growth phase at $6 \mathrm{~h}$, transcription of all glycolytic genes increased simultaneously and reached a maximum level in the mid-exponential growth phase $(8 \mathrm{~h})$. After this, the transcription levels decreased while the cells adapted to the late exponential phase. Generally, it appeared that the degree of expression at each growth phase correlated approximately with the glycolytic rate (measured as glucose consumption; Fig. 2E).
Unlike other genes, the expression levels of $p p s$, $p c k$ and malE mRNA were maximal when the cells had completely consumed the glucose in the medium at stationary phase (16 to $18 \mathrm{~h}$; Fig. $3 \mathrm{~S}$ ) and then gradually decreased as the cells reached the later stage of stationary phase (Fig. 3P-R). There was a 10 -fold increase in pps transcripts associated with simultaneous depletion of glucose in the stationary phase relative to the values observed in the midexponential phase (Fig. 3K, P). In addition, there were twofold increases of both pck and malE mRNA in the stationary phase compared with the value measured in exponential phase (Fig. 3N, O, Q, R). The transcripts of the gluconeogenic genes gapB, $p p s$, pck and malE were similar to or less abundant in cells grown in the presence of glucose (Figs 3 and 7). The genes expressed irrespective of the presence of glucose in the medium were confirmed to be constitutively expressed at all growth stages tested.

The observations indicate that most of the glycolytic genes of C. glutamicum are expressed constitutively but are induced to express at higher levels in the presence of glucose after a rather short lag period. Reduced expression was observed during later stages of growth. The close correlation between the time courses of transcription of glycolytic genes supports the view that
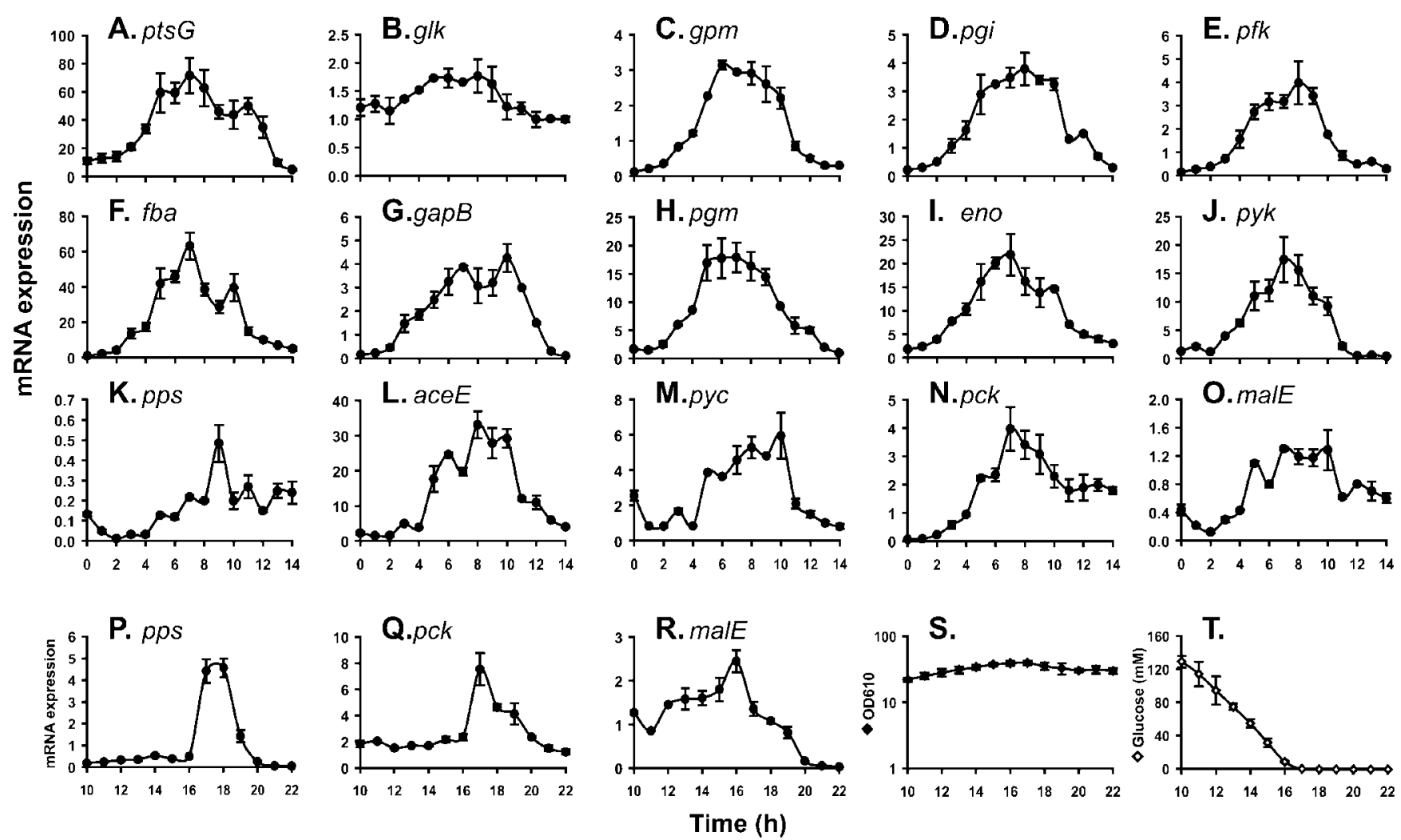

Fig. 3. Relative levels of transcripts of glycolytic genes unlinked to the gapA cluster at different growth phases in glucose culture. The times on the graphs in A-O represent the times of the growth curve in Fig. 2D. (P-R) Expression of pps, pck and malE genes at stationary phase. (S) Growth curve. $(\mathrm{T})$ Time course of glucose concentration. The primers, methods and details correspond to those described in Fig. 2. 
the glycolytic genes are simultaneously expressed to enable glucose utilization.

\section{Expression of glycolytic genes before and after glucose starvation}

To find out whether carbon source withdrawal induces or represses glycolytic gene expression, transcript levels were determined in C. glutamicum before and after starvation of cells grown on either glucose (Fig. 4I) or acetate (Fig. 4II) as sole carbon and energy sources. Firstly, glucose starvation conditions were created when exponential-phase cells from a glucose-containing medium were washed in medium lacking glucose. Expression of most glycolytic genes in a glucose-grown culture, which were clearly observed in unstarved cells, dramatically decreased when the cells were starved for $2 \mathrm{~h}$ (Fig. 4I). In agreement with the previous section (Fig. 3P-R), the genes that were most positively regulated by glucose depletion were gluconeogenic genes such as pps, pck and malE (Fig. 4I-K, O, P). Glucose starvation for about $1.5 \mathrm{~h}$ provoked a 10 -fold increase of pps mRNA (Fig. 4I-K). Expression of pck was also strongly stimulated by glucose starvation, increasing 3.5-fold after about $1 \mathrm{~h}$ (Fig. 4I-O). After about $0.5 \mathrm{~h}$ glucose starvation, transcripts of gapB and malE were depressed, but later markedly increased until about $2 \mathrm{~h}$ starvation. In contrast to the other glycolytic genes, the level of $g l k$ transcripts increased during the initial $0.5 \mathrm{~h}$ of starvation, but decreased during next $1 \mathrm{~h}$ (Fig. 4I-B). Upon further starvation $(2 \mathrm{~h})$, the transcripts increased (Fig. 4I-B).

We next investigated whether this induction was specific to glucose withdrawal or a general consequence of carbon depletion. Accordingly, cells were grown on acetate and then washed in the absence of the carbon source. The expression pattern of glycolytic genes upon acetate depletion was similar to that upon glucose depletion, the only variation being in the level of expression (Fig. 4). In acetate-starved cells, transcripts of most glycolytic genes were depressed (Fig. 4II). However, a threefold increase of pps transcript was observed after $0.5 \mathrm{~h}$ starvation (Fig. 4II$\mathrm{K})$. Furthermore, acetate depletion was associated with an increase in $p y c$ and malE, but not pck expression, after about $0.5 \mathrm{~h}$ (Fig. 4II-N, P, O). After $2 \mathrm{~h}$ starvation, glk and gap $B$ transcripts regained their pre-starvation levels (Figs 4II-B, G).

\section{Glycolytic gene expression response to glucose addition to acetate culture}

To determine whether glucose as a preferred carbon and energy source acts by repressing transcription of glycolytic genes involved in catabolism of subordinate substrates such as acetate, we performed qRT-PCR analysis with specific primer sets. C. glutamicum was grown with acetate (200 mM) until the mid-exponential phase of growth
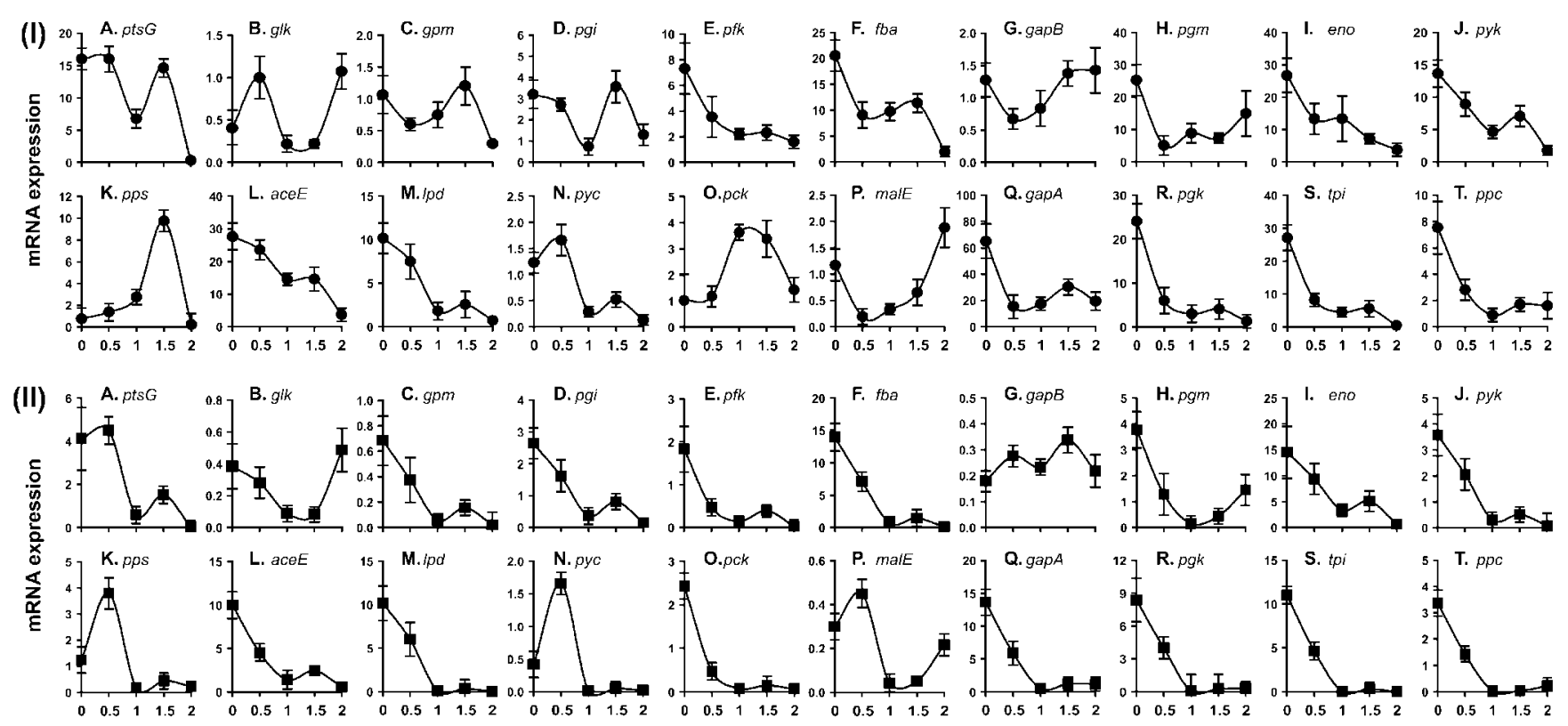

Time (h)

Fig. 4. Levels of transcripts of glycolytic genes analysed by qRT-PCR before and after carbon starvation at exponential phase. Cells grown in mineral salts medium containing $200 \mathrm{mM}$ glucose (I) or acetate (II) as a carbon and energy source were harvested at exponential phase $\left(\mathrm{OD}_{610} 10\right)$ by centrifugation at $6000 \mathrm{~g}$ for $5 \mathrm{~min}$ and washed twice with non-carbon mineral salts medium. Cells were resuspended in non-carbon mineral salts medium to a final $O D_{610}$ of $1-2$ and incubated for $2 \mathrm{~h}$ at $33{ }^{\circ} \mathrm{C}$. The primers, methods and details correspond to those described in Fig. 2. 
and then incubated for an additional $2 \mathrm{~h}$ after supplementation with $200 \mathrm{mM}$ glucose. Addition of glucose in the presence of acetate strongly induced the expression of most glycolytic genes (Fig. 5). However, the pck transcripts were repressed after the culture had been incubated for $0.5 \mathrm{~h}$ (Fig. 5O). The pck transcripts were slightly induced again afterwards (Fig. 5O). It was separately observed that the most favourable inducer of pck mRNA was acetate rather than glucose (see Fig. 7xix). Glucose addition induced the expression of the $p p s, p y c$ and malE genes during the initial $1-1.5 \mathrm{~h}$ incubation, and then a clear reduction of expression to basal levels was observed after $2 \mathrm{~h}$ (Fig. 5K, N, P). In this study, transcription of only few gluconeogenic genes, such as $p c k$, was shown to be repressed when glucose was present but slightly derepressed upon coutilization of glucose and acetate. This analysis demonstrated that glucose causes a rapid repression of certain genes of gluconeogenic metabolism of C. glutamicum.

\section{GIxR binding analysis to the promoter region of glycolytic genes}

To examine GlxR's involvement in controlling the expression of glycolytic genes, we determined the ability of purified GlxR to bind to DNA fragments carrying the promoter region of the glycolytic genes in EMSAs. We searched the nucleotide sequence of C. glutamicum for DNA elements with high levels of identity to the GlxR binding motifs found in the promoter/operator region of glycolytic genes. Computational searches (Vector NTI, Invitrogen) revealed the highest match ( $59.4 \%$ identity) with the consensus CRP-binding site (CBS; $5^{\prime}-\mathrm{TGTGA}^{-} \mathrm{N}_{6}$ ACACT- $\left.3^{\prime}\right)$ in the upstream regions of $f b a\left(\right.$ gGTcA- $_{6^{-}}$ ACACT), gapA (TGTGA- $\mathrm{N}_{6}$ - $\mathrm{tCACa}$ ) and $p c k$ (TGaGA- $\mathrm{N}_{6}$ ACACa). The nucleotide-level identity of GlxR binding motifs in the $a c e B$ promoter region previously described (gGTGA-N ${ }_{6}$-tCACT) (Kim et al., 2004; Letek et al., 2006) was $59.4 \%$.

As indicated in the previous section (Fig. 5O), expression of $p c k$ was found to be subject to glucose repression. Hence we first tested whether GlxR recognizes and binds to the promoter region of the pck gene by doing EMSAs with a 200 bp DNA fragment containing the pck promoter region (Fig. 6, lanes 27 and 28). When cAMP was added to the binding mixture, a clear band shift was observed for $p c k$ (Fig. 6, lane 28) as with the positive control aceB (Fig. 6, lane 32). In addition, the DNA fragment containing sequences far upstream of gapA (288-488 bases upstream of the ATG start codon) appeared to bind to GlxR (Fig. 6, lane 10). Interaction of GlxR with the promoter regions of other glycolytic genes, including $f b a$, was not found (Fig. 6).

\section{Induction of glycolytic genes in response to different carbon sources}

To complete our understanding of the regulation of expression by glycolytic and gluconeogenic carbon sources, we measured the amount of glycolytic gene transcripts in C. glutamicum cells grown in medium containing different carbon substrates as a sole carbon and energy source. The levels of the glycolytic gene transcripts varied considerably with the nature of the carbon source (Fig. 7i-xx). In the presence of glucose, most glycolytic genes ( $p t s G, g p m$, $p f k$, $f b a, t p i, g a p A, p g k, p g m, p y k, a c e E$ and $p p c$ ) were induced to their highest levels (Fig. 7). Gluconeogenic carbon sources such as pyruvate and lactate along with acetate were observed to stimulate the expression of $g l k, p g i, g a p B, p y c$, pck and malE, which might be involved in gluconeogenic metabolism (Fig. 7). Succinate was a relatively good inducer for the glycolytic genes $p g i, g a p B, p p s$, aceE, $p y c$

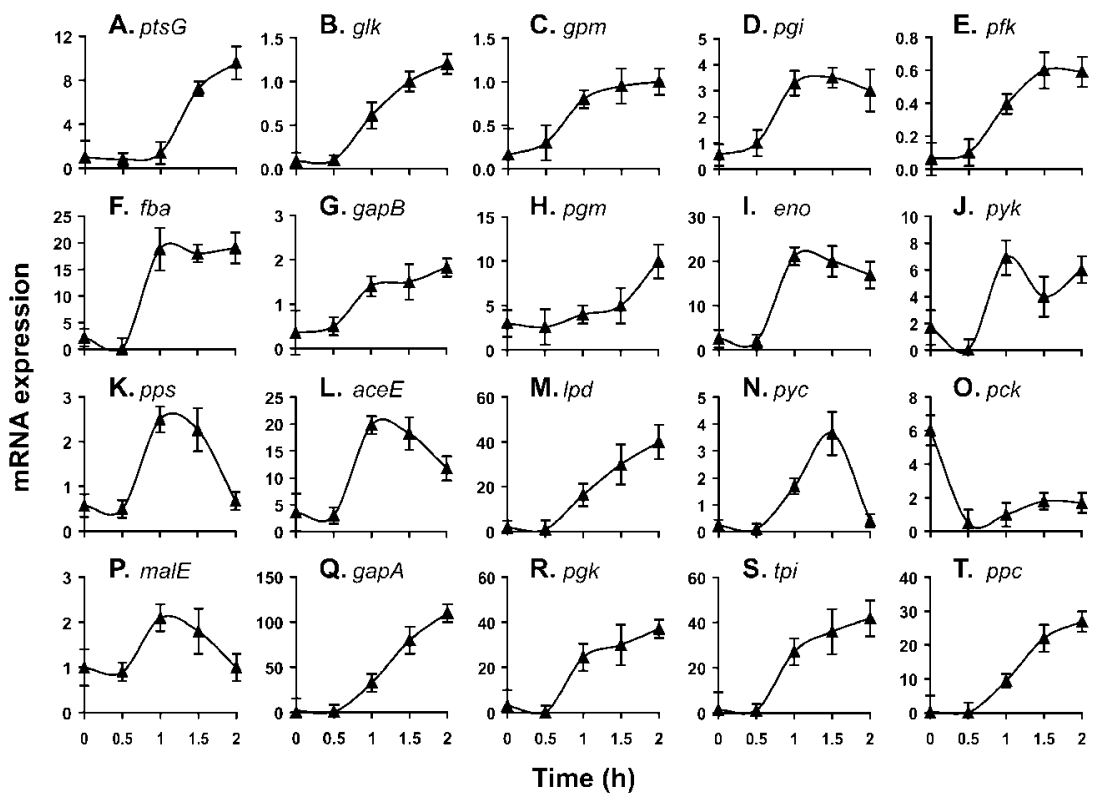

Fig. 5. Time-course of transcription during growth of C. glutamicum on acetate medium with subsequent glucose supplementation, as determined by qRT-PCR. Total RNA (50 ng) was isolated from cells grown on $200 \mathrm{mM}$ acetate medium supplemented with $200 \mathrm{mM}$ glucose. The primers, methods and details correspond to those described in Fig. 2. 


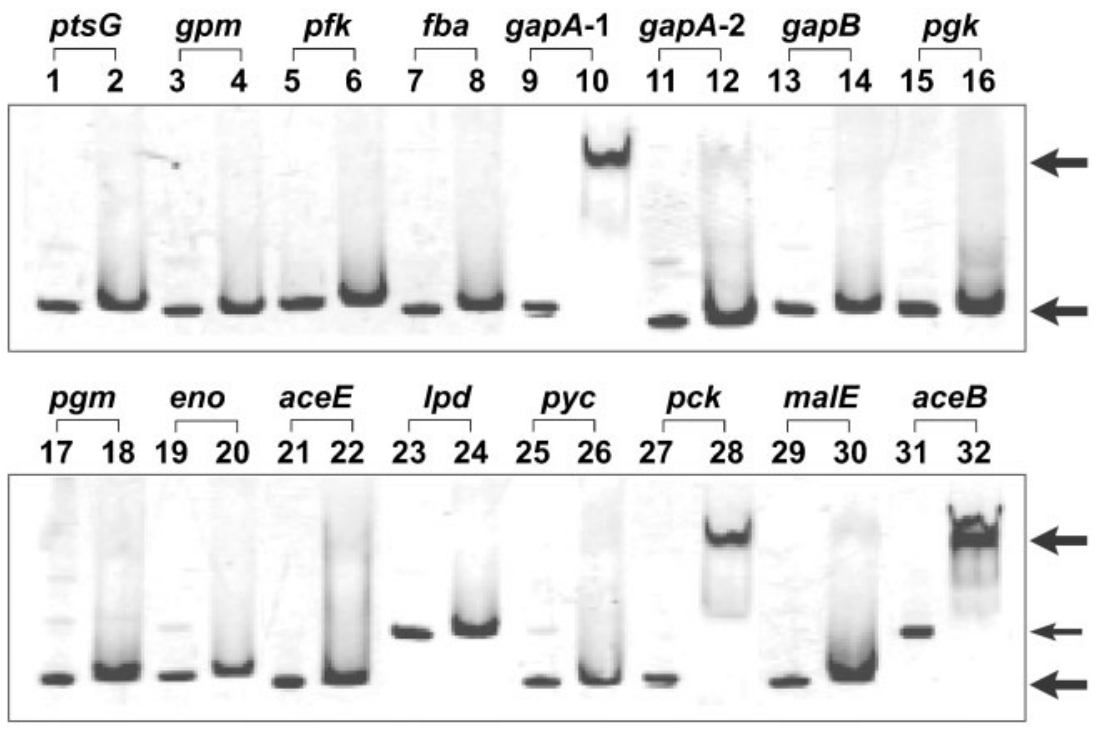

Fig. 6. EMSA with GlxR and glycolytic genes. Lanes with odd numbers contained only the DNA fragment in the reaction mixture; lanes with even numbers contained purified GlxR protein with DNA fragments. Arrows indicate shifted bands. The small arrow indicates the location of large DNA fragments (Ipd, $321 \mathrm{bp}$ and aceB, $329 \mathrm{bp})$.

and malE (Fig. 7). Relatively lower levels of transcripts of all tested genes, except eno and $p p s$, were observed in citrate- or malate-grown cultures. Expression of gapA (Fig. 7viii) was about threefold lower and $g a p B$ expression (Fig. 7ix) about twofold higher for gluconeogenic carbon sources than for glucose cultures. These results indicate that glucose generally induced glycolytic enzymes, but acetate, pyruvate and lactate did induce a number of gluconeogenic genes such as $g a p B, p p s, p y c$ and $p c k$.

\section{DISCUSSION}

To investigate the expression pattern of glycolytic genes, mRNA was isolated from glucose-grown cells taken at various time points. These studies revealed that these genes were coordinately and specifically upregulated by the presence of glucose in the growth medium, and in all cases, qRT-PCR, RLM-RACE and Northern blot experiments revealed that this regulation was due to transcriptional

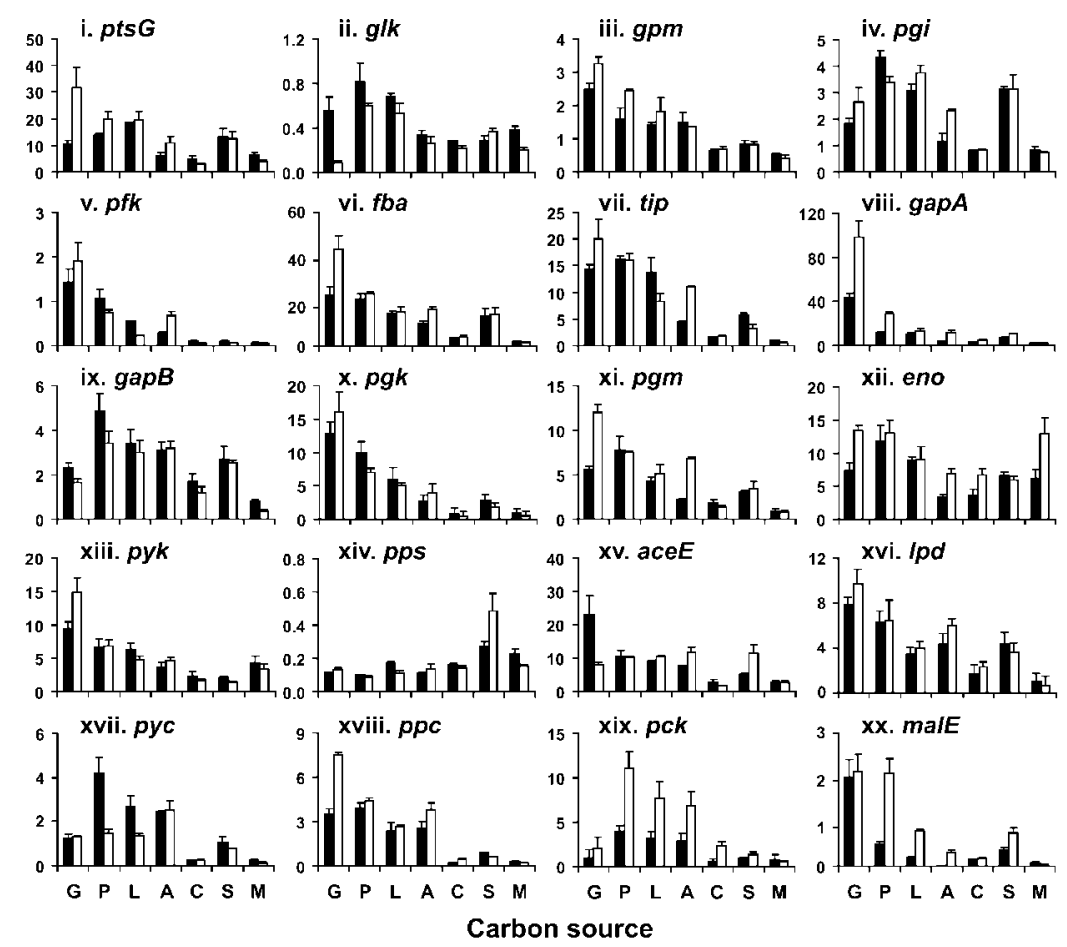

Fig. 7. Levels of induction of C. glutamicum glycolytic genes by different carbon sources. Total RNA (25 ng) was isolated from $C$. glutamicum grown on mineral salts media at 30 min (black bars) and 60 min (white bars) after addition of different sole carbon and energy sources (200 mM): G, glucose; $P$, pyruvate; L, lactate; A, acetate; C, citrate; S, succinate; or $\mathrm{M}$, malate. The primers, methods and details correspond to those described in Fig. 2. 
control of the respective genes. These results suggest that a common mechanism may exist at the transcriptional level for regulation of glycolytic genes by glucose. An interesting influence of growth phase on the transcriptional organization of the gapA operon was found. The transcription of the gapA-pgk-tpi cluster involved mono-, di- and tricistronic mRNAs (Schwinde et al., 1993). This study indicated that highly regulated synthesis of gapA was found during most of the exponential growth phase, with the level being the highest at the mid-exponential phase (Fig. 2). However, expression of the downstream gapA gene was only significantly regulated during the mid-exponential phase. The present observations indicated that most of the glycolytic genes of C. glutamicum were constitutively expressed in the presence or absence of glucose. Although being a general inducing compound for glycolytic genes, glucose strongly induced expression of most of the glycolytic genes such as gapA (Figs 2, 3 and 7). On the other hand, gapB was induced during growth of C. glutamicum on pyruvate, lactate or acetate (Fig. 7). These results indicated that gapA and gapB in C. glutamicum are inversely regulated, which supported previous reports for B. subtilis (Fillinger et al., 2000; Yoshida et al., 2001). Recently, the involvement of the gapB product of C. glutamicum in gluconeogenesis was confirmed by a gene inactivation study and validation of expression data at the level of enzyme activity (Omumasaba et al., 2004). It is apparent that C. glutamicum needs to perform gluconeogenesis rather than glycolysis in the absence of glucose. In general, the expression profiles obtained from C. glutamicum grown on different carbon sources agree with the direction of intracellular carbon fluxes. In glucose cultures, the phosphotransferase system for glucose uptake and glycolytic genes were highly upregulated compared with those in gluconeogenic cultures. We observed a strong correlation between the apparent glycolytic rate and the degree of induction of glycolytic gene expression.

Another interesting observation was that glucose starvation and/or carbon source utilization appeared to have a major effect on transcriptional control of the genes of the PEPpyruvate-oxaloacetate node (Pck converts oxaloacetate to PEP, and MalE plus Pps convert malate to PEP), with gluconeogenic carbon sources such as acetate, pyruvate and lactate inducing maximum expression levels. Expression of $p p s$, pck and malE was two- to fivefold higher when glucose was depleted in the medium (Figs 3 and 4). The most striking difference in regulation of pck between glucosegrown and gluconeogenic carbon source-grown C. glutamicum cultures was manifested in the threefold elevated transcription in cells grown on pyruvate and the twofold higher transcription in cells grown on lactate or acetate when compared with cells grown on glucose (Fig. 7). The gluconeogenic function of Pck in C. glutamicum was shown by inactivation experiments (Riedel et al., 2001). In contrast to the wild-type strain, a defined Pck-deficient mutant was unable to grow on substrates that required gluconeogenesis. As a consequence of carbon-source-dependent regulation of
malE in C. glutamicum (Figs 3, 4 and 7), malic enzyme may not contribute to gluconeogenesis during growth on carbon sources such as acetate or citrate. During growth of $C$. glutamicum on pyruvate or lactate, malic enzyme activity was higher than during growth on acetate, and under these conditions malic enzyme has been proposed to have a role in the generation of NADPH on substrates known to have a low flux through the pentose pathway (Gourdon et al., 2000; Netzer et al., 2004). The transcriptional control of pyruvate carboxylase by carbon source was verified by qRT-PCR data, with pyruvate being the best carbon source for achieving maximum expression levels (Fig. 7). Such an effect has been previously observed in C. glutamicum (Koffas et al., 2002; Peters-Wendisch et al., 1998) and other organisms such as $S$. cerevisiae (Brewster et al., 1994). Our results indicate that certain carbon sources preferentially induce high levels of expression of one gene or a set of genes. These results give a general picture of the potential of glycolytic and/or gluconeogenic gene expression control in response to carbon source and/or growth phase. Furthermore, these results support the hypotheses that there is coordinated expression of some glycolysis and gluconeogenesis genes, that a glucose starvation type of mechanism regulates gluconeogenic gene expression in glucose-deficient cells, and that the presence of accumulated gluconeogenic carbon sources has an effect on carbon utilization by the cells.

The $g l x R$ gene was identified as a putative crp (catabolite repression protein) gene in C. glutamicum using the crp homologues of Mycobacterium and Streptomyces (Kim et al., 2004; Letek et al., 2006). EMSA using purified GlxR from C. glutamicum with DNA fragments of gapA or pck showed a specific DNA-GlxR interaction (Fig. 6). However, the physical positions of a CBS upstream of pck and gapA could be a critical determining factor for the modulation of gene expression, as with catabolite responsive element sequences (Miwa \& Fujita, 2001). In the case of $p c k$, the hypothetical CBS is located close to the -35 box, and therefore its inherent promoter activity could be lower and could strengthen the repressor effect of the carbon sources (Figs 3Q, 4I-O, 5O and 7xix). The contrary may be true for gapA, where the CBS is located far upstream of the -35 box. Therefore, based on our results for the regulation of the pck genes on different carbon sources and the interaction of GlxR with the promoter region of $p c k$, we can conclude that $p c k$, encoding PEP carboxykinase and therefore in principle capable of catalysing the first step in gluconeogenesis in C. glutamicum, is subject to carbon catabolite regulation mediated by cAMP and GlxR.

The first detailed compilation of promoters of the entire set of genes involved in glycolysis is reported in this paper. Alignment of these promoters revealed that they were similar to the consensus B. subtilis $\left(\sigma^{\mathrm{A}}\right)$ promoter (Chang et al., 1992). The close similarity of the promoter to the consensus $\sigma^{\text {A }}$ sequence among glycolytic genes suggests that these promoters, if not subjected to any regulatory constraints, would act as strong promoters in vivo (Hawley \& McClure, 1983). Promoter recognition specificity is 
conferred on RNA polymerase by the sigma factor. The sigma factor gene sigA was cloned and the encoded protein exhibited significant homology to the primary sigma factor of related Gram-positive micro-organisms (Haldenwang, 1995; Predich et al., 1995; Sauer et al., 1994). SigA, the principal sigma factor of corynebacteria, was predominantly expressed during the early exponential phase. The mechanism of control of gene transcription in glycolytic genes appeared to be similar, where the sigma factor showed the same promoter recognition properties. More work is needed to identify the factors determining promoter recognition by the RNA polymerase from C. glutamicum. We hope to gain insight into the properties of C. glutamicum promoter regions in order to genetically engineer and to control expression of these genes. Overall, this research should lead to an improved understanding of how glycolytic and gluconeogenic genes are regulated in C. glutamicum.

\section{ACKNOWLEDGEMENTS}

We are especially grateful to Roy H. Doi (University of California, Davis, CA, USA) and Crispinus Omumasaba for critical reading of the manuscript and for helpful comments. This work was supported by a grant from the Ministry of Economy, Trade and Industry (METI).

\section{REFERENCES}

Barreiro, C., Gonzalez-Lavado, E., Patek, M. \& Martin, J.-F. (2004). Transcriptional analysis of the groES-groEL1, groEL2, and dnaK genes in Corynebacterium glutamicum: characterization of heat shockinduced promoters. J Bacteriol 186, 4813-4817.

Brewster, N. K., Val, D. L., Walker, M. E. \& Wallace, J. C. (1994), Regulation of pyruvate carboxylase isozyme (PYC1, PYC2) gene expression in Saccharomyces cerevisiae during fermentative and nonfermentative growth. Arch Biochem Biophys 311, 62-71.

Bruckner, R. \& Titgemeyer, F. (2002). Carbon catabolite repression in bacteria: choice of the carbon source and autoregulatory limitation of sugar utilization. FEMS Microbiol Lett 209, 141-148.

Chang, B. Y., Shyu, Y. T. \& Doi, R. H. (1992). The interaction between Bacillus subtilis sigma-A $\left(\sigma^{\mathrm{A}}\right)$ factor and RNA polymerase with promoters. Biochimie 74, 601-612.

Chassagnole, C., Diano, A., Letisse, F. \& Lindley, N. D. (2003). Metabolic network analysis during fed-batch cultivation of Corynebacterium glutamicum for pantothenic acid production: first quantitative data and analysis of by-product formation. J Biotechnol 104, 261-272.

de Crombrugghe, B., Busby, S. \& Buc, H. (1984). Cyclic AMP receptor protein: role in transcription activation. Science 224, 831-838.

Dominguez, H., Rollin, C., Guyonvarch, A., Guerquin-Kern, J. L., Cocaign-Bousquet, M. \& Lindley, N. D. (1998). Carbon-flux distribution in the central metabolic pathways of Corynebacterium glutamicum during growth on fructose. Eur J Biochem 254, 96-102.

Dover, L. G., Cerdeno-Tarraga, A. M., Pallen, M. J., Parkhill, J. \& Besra, G. S. (2004). Comparative cell wall core biosynthesis in the mycolated pathogens, Mycobacterium tuberculosis and Corynebacterium diphtheriae. FEMS Microbiol Rev 28, 225-250.

Eikmanns, B. J. (1992). Identification, sequence analysis, and expression of a Corynebacterium glutamicum gene cluster encoding the three glycolytic enzymes glyceraldehyde-3-phosphate dehydrogenase, 3-phosphoglycerate kinase, and triosephosphate isomerase. $J$ Bacteriol 174, 6076-6086.

Eikmanns, B. (2005). Central metabolism: tricarboxylic acid cycle and anaplerotic reactions. In Handbook on Corynebacterium glutamicum, pp. 241-276. Edited by L. Eggeling \& M. Bott. Boca Raton, FL: CRC Press.

Fillinger, S., Boschi-Muller, S., Azza, S., Dervyn, E., Branlant, G. \& Aymerich, S. (2000). Two glyceraldehyde-3-phosphate dehydrogenases with opposite physiological roles in a nonphotosynthetic bacterium. J Biol Chem 275, 14031-14037.

Funke, G., von Graevenitz, A., Clarridge, J. E., III \& Bernard, K. A. (1997). Clinical microbiology of coryneform bacteria. Clin Microbiol Rev 10, 125-159.

Gerstmeir, R., Wendisch, V. F., Schnicke, S., Ruan, H., Farwick, M., Reinscheid, D. \& Eikmanns, B. J. (2003). Acetate metabolism and its regulation in Corynebacterium glutamicum. J Biotechnol 104, 99-122.

Gourdon, P., Baucher, M. F., Lindley, N. D. \& Guyonvarch, A. (2000). Cloning of the malic enzyme gene from Corynebacterium glutamicum and role of the enzyme in lactate metabolism. Appl Environ Microbiol 66, 2981-2987.

Gubler, M., Jetten, M., Lee, S. H. \& Sinskey, A. J. (1994). Cloning of the pyruvate kinase gene ( $p y k$ ) of Corynebacterium glutamicum and site-specific inactivation of $p y k$ in a lysine-producing Corynebacterium lactofermentum strain. Appl Environ Microbiol 60, 2494-2500.

Haldenwang, W. G. (1995). The sigma factors of Bacillus subtilis. Microbiol Rev 59, 1-30.

Harley, C. B. \& Reynolds, R. P. (1987). Analysis of E. coli promoter sequences. Nucleic Acids Res 15, 2343-2361.

Hauf, J., Zimmermann, F. K. \& Muller, S. (2000). Simultaneous genomic overexpression of seven glycolytic enzymes in the yeast Saccharomyces cerevisiae. Enzyme Microb Technol 26, 688-698.

Hawley, D. K. \& McClure, W. R. (1983). Compilation and analysis of Escherichia coli promoter DNA sequences. Nucleic Acids Res 11, 2237-2255.

Hayashi, M., Mizoguchi, H., Shiraishi, N., Obayashi, M., Nakagawa, S., Imai, J., Watanabe, S., Ota, T. \& Ikeda, M. (2002). Transcriptome analysis of acetate metabolism in Corynebacterium glutamicum using a newly developed metabolic array. Biosci Biotechnol Biochem 66, 1337-1344.

Huser, A. T., Becker, A., Brune, I., Dondrup, M., Kalinowski, J., Plassmeier, J., Puhler, A., Wiegrabe, I. \& Tauch, A. (2003). Development of a Corynebacterium glutamicum DNA microarray and validation by genome-wide expression profiling during growth with propionate as carbon source. J Biotechnol 106, 269-286.

Huser, A. T., Chassagnole, C., Lindley, N. D., Merkamm, M., Guyonvarch, A., Elisakova, V., Patek, M., Kalinowski, J., Brune, I. \& other authors (2005). Rational design of a Corynebacterium glutamicum pantothenate production strain and its characterization by metabolic flux analysis and genome-wide transcriptional profiling. Appl Environ Microbiol 71, 3255-3268.

Ikeda, M. \& Nakagawa, S. (2003). The Corynebacterium glutamicum genome: features and impacts on biotechnological processes. Appl Microbiol Biotechnol 62, 99-109.

Inui, M., Murakami, S., Okino, S., Kawaguchi, H., Vertes, A. A. \& Yukawa, H. (2004). Metabolic analysis of Corynebacterium glutamicum during lactate and succinate productions under oxygen deprivation conditions. J Mol Microbiol Biotechnol 7, 182-196.

Kalinowski, J., Bathe, B., Bartels, D., Bischoff, N., Bott, M., Burkovski, A., Dusch, N., Eggeling, L., Eikmanns, B. J. \& other authors (2003). The complete Corynebacterium glutamicum ATCC 
13032 genome sequence and its impact on the production of aspartate-derived amino acids and vitamins. J Biotechnol 104, 5-25.

Kim, H. J., Kim, T. H., Kim, Y. \& Lee, H. S. (2004). Identification and characterization of $g l x R$, a gene involved in regulation of glyoxylate bypass in Corynebacterium glutamicum. J Bacteriol 186, 3453-3460.

Kinoshita, S. \& Tanaka, K. (1972). Glutamic acid. In The Microbial Production of Amino Acids, pp. 263-324. Edited by K. Yamada. New York: John Wiley.

Kinoshita, S., Udaka, S. \& Shimono, M. (1957). Studies on the amino acid fermentation Part I. Production of L-glutamic acid by various microorganisms. J Gen Microbiol 3, 193-205.

Koffas, M. A., Jung, G. Y., Aon, J. C. \& Stephanopoulos, G. (2002). Effect of pyruvate carboxylase overexpression on the physiology of Corynebacterium glutamicum. Appl Environ Microbiol 68, 5422-5428.

Kolb, A., Busby, S., Buc, H., Garges, S. \& Adhya, S. (1993). Transcriptional regulation by cAMP and its receptor protein. Annu Rev Biochem 62, 749-795.

Kotrba, P., Inui, M. \& Yukawa, H. (2001). The ptsI gene encoding enzyme I of the phosphotransferase system of Corynebacterium glutamicum. Biochem Biophys Res Commun 289, 1307-1313.

Laemmli, U. K. (1970). Cleavage of structural proteins during the assembly of the head of bacteriophage T4. Nature 227, 680-685.

Letek, M., Valbuena, N., Ramos, A., Ordonez, E., Gil, J. A. \& Mateos, L. M. (2006). Characterization and use of catabolite-repressed promoters from gluconate genes in Corynebacterium glutamicum. J Bacteriol 188, 409-423.

Liebl, W. (1991). The genus Corynebacterium - nonmedical. In The Prokaryotes, pp. 1157-1171. Edited by A. Balows, H. G. Trüper, M. Dworkin, W. Harder \& K. H. Schleifer. New York: SpringerVerlag.

Liebl, W. (2005). Corynebacterium taxonomy. In Handbook on Corynebacterium Glutamicum, pp. 9-34. Edited by L. Eggeling \& M. Bott. Boca Raton, FL: CRC Press.

Lorca, G. L., Chung, Y. J., Barabote, R. D., Weyler, W., Schilling, C. H. \& Saier, M. H., Jr (2005). Catabolite repression and activation in Bacillus subtilis: dependency on CcpA, HPr, and HprK. J Bacteriol 187, 7826-7839.

Ludwig, H., Homuth, G., Schmalisch, M., Dyka, F. M., Hecker, M. \& Stulke, J. (2001). Transcription of glycolytic genes and operons in Bacillus subtilis: evidence for the presence of multiple levels of control of the gapA operon. Mol Microbiol 41, 409-422.

Meng, W., Belyaeva, T., Savery, N. J., Busby, S. J., Ross, W. E., Gaal, T., Gourse, R. L. \& Thomas, M. S. (2001). UP element-dependent transcription at the Escherichia coli $\mathrm{rrnB}$ P1 promoter: positional requirements and role of the RNA polymerase alpha subunit linker. Nucleic Acids Res 29, 4166-4178.

Miwa, Y. \& Fujita, Y. (2001). Involvement of two distinct cataboliteresponsive elements in catabolite repression of the Bacillus subtilis myo-inositol (iol) operon. J Bacteriol 183, 5877-5884.

Muffler, A., Bettermann, S., Haushalter, M., Horlein, A., Neveling, U., Schramm, M. \& Sorgenfrei, O. (2002). Genome-wide transcription profiling of Corynebacterium glutamicum after heat shock and during growth on acetate and glucose. J Biotechnol 98, 255-268.

Netzer, R., Krause, M., Rittmann, D., Peters-Wendisch, P. G., Eggeling, L., Wendisch, V. F. \& Sahm, H. (2004). Roles of pyruvate kinase and malic enzyme in Corynebacterium glutamicum for growth on carbon sources requiring gluconeogenesis. Arch Microbiol 182, 354-363.

Omumasaba, C. A., Okai, N., Inui, M. \& Yukawa, H. (2004). Corynebacterium glutamicum glyceraldehyde-3-phosphate dehydrogenase isoforms with opposite, ATP-dependent regulation. J Mol Microbiol Biotechnol 8, 91-103.
Park, S. Y., Kim, H. K., Yoo, S. K., Oh, T. K. \& Lee, J. K. (2000). Characterization of $g l k$, a gene coding for glucose kinase of Corynebacterium glutamicum. FEMS Microbiol Lett 188, 209-215.

Patek, M., Nesvera, J., Guyonvarch, A., Reyes, O. \& Leblon, G. (2003). Promoters of Corynebacterium glutamicum. J Biotechnol 104, 311-323.

Perez-Martin, J., Rojo, F. \& de Lorenzo, V. (1994). Promoters responsive to DNA bending: a common theme in prokaryotic gene expression. Microbiol Rev 58, 268-290.

Peters-Wendisch, P. G., Kreutzer, C., Kalinowski, J., Patek, M., Sahm, H. \& Eikmanns, B. J. (1998). Pyruvate carboxylase from Corynebacterium glutamicum: characterization, expression and inactivation of the $p y c$ gene. Microbiology 144, 915-927.

Predich, M., Doukhan, L., Nair, G. \& Smith, I. (1995). Characterization of RNA polymerase and two sigma-factor genes from Mycobacterium smegmatis. Mol Microbiol 15, 355-366.

Riedel, C., Rittmann, D., Dangel, P., Mockel, B., Petersen, S., Sahm, H. \& Eikmanns, B. J. (2001). Characterization of the phosphoenolpyruvate carboxykinase gene from Corynebacterium glutamicum and significance of the enzyme for growth and amino acid production. J Mol Microbiol Biotechnol 3, 573-583.

Ross, W., Aiyar, S. E., Salomon, J. \& Gourse, R. L. (1998). Escherichia coli promoters with UP elements of different strengths: modular structure of bacterial promoters. J Bacteriol 180, 5375-5383.

Sahm, H., Eggeling, L., Eikmanns, B. \& Kramer, R. (1995). Metabolic design in amino acid producing bacterium Corynebacterium glutamicum. FEMS Microbiol Rev 16, 243-252.

Saier, M. H., Jr, Chauvaux, S., Deutscher, J., Reizer, J. \& Ye, J. J. (1995). Protein phosphorylation and regulation of carbon metabolism in gram-negative versus gram-positive bacteria. Trends Biochem Sci 20, 267-271.

Sauer, U., Treuner, A., Buchholz, M., Santangelo, J. \& Durre, P. (1994). Sporulation and primary sigma factor homologous genes in Clostridium acetobutylicum. J Bacteriol 176, 6572-6582.

Schreiner, M. E., Fiur, D., Holatko, J., Patek, M. \& Eikmanns, B. J. (2005). E1 enzyme of the pyruvate dehydrogenase complex in Corynebacterium glutamicum: molecular analysis of the gene and phylogenetic aspects. J Bacteriol 187, 6005-6018.

Schwinde, J. W., Thum-Schmitz, N., Eikmanns, B. J. \& Sahm, H. (1993). Transcriptional analysis of the gap-pgk-tpi-ppc gene cluster of Corynebacterium glutamicum. J Bacteriol 175, 3905-3908.

Schwinde, J. W., Hertz, P. F., Sahm, H., Eikmanns, B. J. \& Guyonvarch, A. (2001). Lipoamide dehydrogenase from Corynebacterium glutamicum: molecular and physiological analysis of the lpd gene and characterization of the enzyme. Microbiology 147, 2223-2231.

Stulke, J. \& Hillen, W. (2000). Regulation of carbon catabolism in Bacillus subtilis. Annu Rev Microbiol 54, 849-880.

Wittmann, C. \& De Graaf, A. A. (2005). Metabolic flux analysis in Corynebacterium glutamicum. In Handbook on Corynebacterium glutamicum, pp. 277-304. Edited by L. Eggeling \& M. Bott. Boca Raton, FL: CRC Press.

Yokota, A. \& Lindley, N. D. (2005). Central metabolism: sugar uptake and conversion. In Handbook on Corynebacterium glutamicum, pp. 215-240. Edited by L. Eggeling \& M. Bott. Boca Raton, FL: CRC Press. Yoshida, K., Kobayashi, K., Miwa, Y., Kang, C. M., Matsunaga, M., Yamaguchi, H., Tojo, S., Yamamoto, M., Nishi, R. \& other authors (2001). Combined transcriptome and proteome analysis as a powerful approach to study genes under glucose repression in Bacillus subtilis. Nucleic Acids Res 29, 683-692.

Edited by: T. Nihira 